\title{
Perjury and Its Effects in the View of Jurisprudence and Criminal Law
}

\author{
Ahmadi Seyed Mehdi ${ }^{1}$ \\ ${ }^{1}$ Department of Islamic Law and Jurisprudence Group, Sari branch, Islamic Azad University, Sari, Iran \\ Correspondence: Ahmadi Seyed Mehdi, Department of Islamic Law and Jurisprudence Group, Sari branch, \\ Islamic Azad University, Sari, Iran. E-mail: dr.ahmadi4545@gmail.com
}

Received: February 2, 2016 Accepted: June 8, 2016 Online Published: October 30, 2016

doi:10.5539/jpl.v9n9p22

URL: http://dx.doi.org/10.5539/jpl.v9n9p22

\begin{abstract}
Importance of testimony of witnesses as one of the reasons for proving the dispute has long story in our jurisprudence and criminal law to such extent that in Imamieh jurisprudence the award of judge follows from testimony of witnesses and is considered as a means for finalizing the proceeding. However, if the perjury is proved by documents and evidences and or knowledge of the judge, witness inadvertently encounters with different effects of committed crime. This paper while defining the concept of perjury crime aims to study the elements and building blocks as well as types of punishments determined for this crime and finally analyze and determine the effects of perjury crime in jurisprudence and criminal law.
\end{abstract}

Keywords: testimony, witness, reasons for proving the dispute, perjury

\section{Introduction}

From long times ago, in law of different communities, testimony of witnesses, as one of the reasons for proving the dispute played very important role in resolving the disputes and claims. Witness in Iranian law derived from jurisprudence and Islamic law. Therefore, by definition, witness includes "news of one or a few persons on occurrence or presence of a tangible case in the past or present to such extent that such news doesn't damage to the informer; on the other hand, it means information provided by a person directly from the occurrence of an event.

In Imamieh jurisprudence, testimony is considered individually as a reason for proving a crime; however, in Iranian Criminal Law, testimony of witnesses isn't applicable in criminal affairs and only is a way for knowledge and inference of judge for determining the crime.

Legislator has criminalized the crime of perjury in Tazzirat part in Article 650 of Islamic Punishment Law that has allocated specific properties such as having perjury in the court and before official authorities. This crime is an absolute one and requires no specific bad faith for fulfilling it and its punishment is considered as Tazziri ${ }^{1}$ punishments of grade 6 with its fine is considered as grade 7 .

Thus, according to the importance and value of proving a testimony in Islamic jurisprudence and enacted criminal law, while reviewing the elements of such crime, this study will analyze the legal dimensions and effects of this crime in criminal law and criminal jurisprudence.

\section{Perjury Crime Concept Literally and Terminologically}

\subsection{Literal Concept of Testimony}

Testimony of witness(es) is one of the procedures for proving a dispute in legal and criminal issues. Literally, testimony means presence and examination and notice (Jafari Langroodi, 2002, P. 123); according to linguists, it means becoming aware of a thing by seeing it (Jafari Langroodi, Vol. 5; P. 179). There hasn't been predicted a definition for it in terminology; however, in legal references such as doctrine and common law and most legal books and writings, "certification" has been used as Persian alternative for "testimony"; this process called as situation of vocabulary in meaning has been discussed in fourth section of chapter 10 of third paradigm of Code of Civil Procedure approved in 2000 (Sadri, 2009, P. 62); some elements of defining the testimony includes (1) news; (2) right news; (3) in one's favor; (4) against one.

\footnotetext{
${ }^{1}$ Punishment below the full amount prescribed by law
} 


\subsection{Terminological Concept of Testimony}

Stating the concept of testimony in Iranian law, it could be declared that it is derived from Islamic law and entered to legal context. Testimony by legal and terminological concept means those information that a person obtained from an occurrence directly, i.e. individual sees that event when disputed and it is the provision for accepting the testimony. Article 1320 of Civil Law states that "testimony on a testimony could be only heard when the original witness has deceased and or due to another hindrance such as illness, trip or jail he/ she couldn't attend". Therefore, intermediary testimony is accepted only when its origin, i.e. main witness, is known however due to force majeure events it couldn't attend before the court (Katouzian, 2006, P. 384).

What is stated by witness is considered as a news and it might be right or true. Therefore, witness is somebody who has a news from occurrence of an event in the past or present from what he/ she has heard or seen and what notifies its occurrence is called as "Evident to" and somebody whom testimony is in his favor is called as "Evident in favor" and someone whose testimony is against him/her is called as "Evident Against". (Jafari langroodi, previous, p. 397).

Testimony is also defined as below: "having testimony means narrating an even occurred and witness has seen or heard it or sensed, smelled or tasted it" (Katouzian, 2009, P. 7). There is another definition for testimony: "testimony means news of a person before judge from what he/ she has seen or heard or other cases of information obtained accidentally or upon the request of one of the parties of the dispute" (Shams, 2013, P. 222).

\subsection{Concept of Perjury Crime}

In the fifth book of Islamic Punishment Law (Tazirat and Preventive Punishments), chapter 20 (perjury and revealing the secrete) in Article 50 of Islamic Punishment Law, approved in 2013, perjury has been criminalized as below: "When someone has perjury before official authorities, he/ she will be condemned to three months and one day to two years of jail or paying for fine of one million five hundred thousand from twelve million Rls (however, it is to say that the punishment for this Article, according to new Islamic Punishment Law, will be the same as punishment of grade 8).

Note: The punishment as mentioned in this Article is in addition to punishment as mentioned in chapter of Hodood $^{2}$ and blood money for perjury".

When defining perjury crime, subject of recently mentioned Article, we encounter some properties specific to this crime such as: it must occurred in the court and it doesn't include in this Article out of the court. Mentioning word "court" also includes public court, revolution courts, military courts and courts of clergies (Bahrami, 2008, P. 150).

In addition, testimony in the court must be before official authorities. Official authorities include someone who is qualified hearing the testimony of witness in the court (Shokri, 1999, P. 735).

Therefore, if a person who hears the testimony isn't qualified for such hearing, testifying couldn't be included in this Article. Theory 1379/9/9-7/ 3234 (A.H.G): according to the generality of Article 650 of Tazirat Law (part of Tazirat Crime in previous punishment law) official authorities isn't limited to judicial authorities; therefore, for example, when someone has perjury in the Registry Office that someone owns a child called " $\mathrm{X}$ " and this testimony applied for issuing the Birth Certificate, it will include in Article 654 (Hojati, 2005, P. 1155). On the other hand, testifying in the court according to Article (418) of Civil Procedure law is conducting with oath and swear; i.e. witness attests that he/she says only the truth. According to Article 145 of this law, before stating anything, witnesses must attest as below: "I consider God's view and swear that I say nothing unless truth"; therefore should it have perjury, it will be included in this Article.

\section{Elements of Perjury Crime}

Legal, material and spiritual element of perjury could be detailed as below:

\subsection{Legal Element}

After the conquer of Islamic Revolution and by approval of fifth book of Islamic Punishment Law on May 22, 1996, Article 650 of Islamic Punishment Law with many brevity replaced with Article 215 to 219 of Public Punishment Law, now, this Article is one of the main legal element in the field of perjury remained unchanged when new Islamic Punishment Law approved in 2013.

\footnotetext{
${ }^{2}$ Penance or punishment by the lash as ordained by Islamic region
} 


\subsection{Material Element}

According to Article 650 of this law, material element of this crime is "perjury before official authorities in the court" and it could be separated into three following parts:

\subsubsection{Testifying}

In Islamic Punishment Law approved in 2013, in fifth part of first book called "Reasons of proof in criminal matters" considering Article 174, it defined the testimony. According to this Article, "Testimony means informing the news of a person except parties of dispute to occurrence or non-occurrence of a crime by accused or any other matter before judicial authority". Article 175 also defines legal testimony as below: "legal testimony is what validated by legislator with authority whether it is suitable scientifically or not". Testimony is in favor of one of parties of the dispute and against another one; while confession is a news against oneself and in favor of another one.

Testifying comes with some formalities. According to Article 153 of Procedure Code of Public and Revolution Courts in criminal matters approved on Apr 11, 1999, "witnesses of investigation and informed ones before stating their information must testify as below: I swear the God say nothing unless truth". Note of this Article also states that: "In cases that adjudication requires testimony of an equitable witness and witness denies swearing; his/ her testimony will be heard without oath." According to this Article as well as appearance of Article 650 of Islamic Punishment Law, for fulfilling the perjury crime, swearing by witness isn't a necessary provision for fulfilling the crime and when it has perjury, whether sworn or not, when there are other conditions, it will be subject to the criminal topic.

\subsubsection{False Testimony}

False testimony is a false and unreal news testified by witness by distorting the reality against a person and in favor of another one. It could be stated that what is considered as false crime is testimony not any statement or claim stated by witness. Generally speaking, witness might give some explanations and describe its statements together with testifying and or states that how it was present at place and in this case testifies in favor of someone and against another one.

Certainly, false testimony that could be considered as a crime with criminal liability is merely declarative and is specifically called as "testimony" with properties of being against one and in favor of another one and other arrangements and or introductory and unrelated remarks even though are false, will not include the witness in perjury.

\subsubsection{In the Court before Official Authorities}

Fulfilling the perjury crime, subject of Article 650 of Islamic Punishment Law is subject to this issue that perjury has occurred in the court before official authorities. The sequence between two expressions "court" and "before official authorities" indicates the necessity of presence of both provisions simultaneously. Word "court" is applicable and includes all jurisdictions such as public, revolution, appeals, and provincial criminal, specialized for clergy's courts and Supreme Court and Supreme Administrative Court. Official authorities means all people who legally are qualified and permitted to hear the testimony. The direct result of both provisions is that when perjury applied before official authorities such as official officers in Registry office, Deed Title Registration Department, Embassies and Police Office, however occurred out of the court without related formalities, it will not be subject in this case subject. The same order applies when testifying is in the court but not before official authorities.

By such explanations, theory No. 7/3234 dated Nov 29, 2000 by legal administration of judiciary isn't true. According to this theory, "considering applicability of Article 650 of Islamic Punishment Law, official authorities is not limited to judicial ones. Should someone for example have perjury in Registry Office that someone owns a child called "X" and this testimony applied for issuing the Birth Certificate, it will be included in above Article".

Theory No. 7/5468 dated Oct 24, 2005 of legal administrative has also a similar reasoning. According to this theory "by applying Article 650 of Islamic Punishment Law, official authorities is not limited to judicial ones; therefore, should someone have perjury in the Registry Office for birth date of a person and his testimony affected on issuing the birth certificate and or death certificate, it will be included in above Article..."

Another reasoning for objecting above theories of legal administrative is that there is a specific law in the field of perjury for birth or death of people that cases as mentioned in above advisory opinions is included in that law; according to Article 2 of Law of Violations, Crimes and Punishments for assembly documentations and birth 
certificate approved on Aug 1, 1991 by regime's Expediency Council, people who have perjury about birth or death and their testimony affected in the General Registration Book and or Death Registration Book, the committed persons will be punished to 91 days to one year of jail and or paying for fine from two thousand to one million Rls or both.

The important point is that one could not consider that Islamic Punishment Law has approved after this law followed by abolishing violations law according to Islamic Punishment Law. Because above law is approved by Expediency Council and Islamic Punishment Law approved by Islamic Council Assembly and according to theory No. 5318 dated June 13, 1993 of Guardian Council, Islamic Council Assembly isn't entitled to reject or cancel the regulations and approvals of Expediency Council.

On the other hand, in the Code of Procedure, there hasn't been predicted any case that upon reasons or compromises, the testimony of witnesses could be heard out of the court. In this case, Article 244 of Code of Procedure of Public and Revolution Courts in the civil matters states that: "Should witness deny attending to the court as well as in case of court's discretion, the testimony of the witness could be heard in his/ her home or working place and or in the place of dispute by one of the judges of the court." According to Article 161 of Code of Procedure of Islamic and Revolution Courts for criminal matters, "when witness or informed person is ill and couldn't attend before the court and or the number of witnesses and accused persons is high and resided in a place like laborers of a factory, judge will attend in their site and investigate about the issue"; the question is, during perjury in such cases that it has testified before a judge but out of the court, is this testimony included in Article 650? It seems that according to the appearance of Article 650 and also considering the principle of interpretation in favor of accused person, the provision of "being attended at court" could deny the testimony and perjury crime will be cancelled in the cases as mentioned in above articles. However, it seems that word "court" in Article 650 in addition to being the name of a place and or means a specific place, it means a place and situation where a testimony applied before a judicial qualified authorities base on legal formalities and officially; therefore, one cannot determine a specific property for court as a given building where perjury crime has merely occurred in such a place. Therefore, even in above mentioned cases that testimony has been heard before an official authorities by presence of witnesses, the perjury crime could be fulfilled.

Therefore, testimony expressed by witness in police offices and court even though it is false lacks required conditions as mentioned in Article 650 of Islamic Punishment Law; thus, the witness couldn't be condemned in such case.

No one of both above conditions has been considered in Public Punishment Law; therefore, perjury may not necessarily be applied in the court or before a special authority. According to this law, perjury was of course divided into criminal matters, misdemeanors, ethical issues and administrative issues and in some cases, testifying wasn't possible only before the court. By such records of legislation, it is even likely that word "with" after word "court" and before word "official authorities" have been missed inadvertently and unintentionally.

\subsection{Spiritual Element}

Mental element determines the rate of fault by committer. Committing a crime is either demonstration of a bad intention or faults of the criminal provided that such actor will do such act and or at least consider its likelihood and violates the orders of legislator. In this case, we say that actor either did a deliberate act or violated. What is called as fault in the meaning of actor is either deliberately or by fault. Deliberation is the mental element of crimes so called "Deliberate Crimes" and Criminal error or fault is the mental element of fault crimes (Ardabili, 2009, P. 233).

\subsubsection{Knowledge and Awareness}

Knowledge and awareness of the committer means he/ she knows the order of law for an act and its legal ban. Knowledge is divided into two parts. Knowing the order and knowing the issue; for knowing the orders of this law, it comprises all crimes as well as perjury crime. For knowing the issue, it is unknown when even the committer knows the legal order, however he/ she does not know the issue with order. Ignorance to the issue comes with types: occasionally it is ignorance to the act per se, sometimes it is ignorance to the element of the act and occasionally to the result. In the ignorance to the issue, although actor has enough knowledge that testifying perjury is considered as a crime resulting in punishment, however, he/ she has no knowledge about his act that is a perjury or elements of his act is conformed to a criminal issue.

When mistake and ignorance are among the elements of his act, for example witness assumed that the person who is testifying to him isn't an official authorities and or he does not know that he is stating its expression in an official session of the court; we believe that the penal liability of actor is fulfilled to his act per se, i.e. mistake in 
the banned act that it is unique in part and wholly and its responsibility in this case remained.

For fulfilling the bad intention, it is needed to conform the material act as perceived by actor with an act determined by legislator; for example, he knows the ignorance crime (Article 523 of Islamic Punishment Law, Tazirat); as far as the ignorant knows that its committed act will distort the truth and such distortion results in material and spiritual loss of a person or society, its fault has been proved (Ardabili, same, P. 236).

\subsubsection{Willingness}

Willingness legally means intention for committing an actor or omission of an act banned by law; it means that the acts of accused must be by its will. Should its acts be involuntarily, it wouldn't be applied in criminal liability because no unwilling act could be the subject of fear (Klarson, 2011, P. 55). Crime is fulfilled when actor perform an act or omission of act willingly and voluntarily. Such a requisite called "General Bad Intention"; however, in some crimes, according to legislator, the intention of actor is required for attaining to a specific result called as "Specific Bad Intention".

In the perjury crime according to the appearance of Article 650, it could be indicated that such crime is one of the crimes that a general bad intention is enough for fulfilling it. On the other hand, it is enough for a person to willingly testify perjury in the court before official authorities; thus, his crime is fulfilled. Because it is an absolute crime and incentive for false testimony is not effective in fulfilling the crime and the only effect of incentive is its effect on rebating or toughening the punishment by the judge (clause C, Article 38 of Islamic Punishment Law). It is also considered as deliberate crimes because one cannot include a person in such crime who unintentionally have perjury as the result of qualifying the intention for proving the false case as specifically deliberate or specific bad intention (Saleh Validi, 2010, P. 165).

Proving the perjury crime like other crimes with reasons for proving the provable crime detailed as below:

A- Circumstantial evidences with knowledge like judicial evidences for example the content of testifying is clearly objected to the truth or there are matters that it is impossible by witness to observe or see it or statements of the witness is objected to the details of an event;

B- Confession of the witness;

C- Knowledge of the judge, although the knowledge of the judge has been also obtained by circumstantial evidences, however, it is individually an independent reason that might be created by subjects heard and felt by the judge and any reason could create this knowledge and all reasons will indeed depend on the judge's knowledge; then, by attaining the knowledge of the issue by judge, he may discuss an evident obtained that it is false and based on it, he cannot issue its order (Khalegi, 2011, P. 171).

\section{Punishment for Perjury Crime}

Perjury might result in one of punishments including Taziri, Hadi or Hodood, blood money and or combination of them. Here we will summarize them as below.

\subsection{Taziri Punishment}

According to Article 650, this punishment includes three months and one day to two years of jail and or one million five hundred thousand to twelve million Rls of fine and according to preposition "or" it could be stated that one of above punishments is merely considered in the subject of order. According to Article 19 of Islamic Punishment Law approved in 2013, the jail as mentioned in Article 650 of Tazirat Book is considered as Taziri Punishments of grade 6 with its fine is considered of grade 7.

\subsection{Hadi (Hodood) Punishment}

Extrusion Had is the only Had crime that could be committed by perjury. According to Article 245 of Punishment Law of 2013, should a testimony be testified by witness in the court before official authorities is false comprising attribution of since and watt to another person, the witness will be condemned to both Taziri and Hadi Punishments, and according to Article 250 as mentioned before, extrusion Had is punished to eighty whips. However, extrusion Had is considered as Public Rights and executing the punishment is subject to claim of extruded person (someone whom testified against).

\subsection{Blood Money Punishment}

Perjury crime could result in murder or battery of another person, because of causality the false witness might be convicted to blood money. In Tahrir Al-Vasilah, Imam Khomeini clearly indicated the possibility of causality of witnesses in execution or blood money. In problem 39 of Gesas (Blood Money) Book, he states that: "if two witnesses testify to a thing like heresy causing murder, and or four people testify to what is causing stoning like 
adultery and after executing the Had or blood money, it is proved that they committed perjury, neither judge nor execution officer is responsible and false witness must be punished by blood money. However, when blood guardian requests for blood money in false and witnesses also perjury in this case whether blood money is applied for all of them or on blood guardian, there are some dimensions that the closest one to the accuracy is the responsibility of witnesses (Al-Mousavi Al-Khomeini, 1403, G., Vol. 2, P. 519).

Considering later and based on note of Article 650 of Islamic Punishment Law, when a witness causes the blood money or execution of another person by perjury, in addition to Tazziri punishment for this crime, the false witness must pay for blood money.

\section{Effects of Perjury in Jurisprudence and Criminal Law}

\subsection{Effects of Perjury and its Criminal Liability in Criminal Jurisprudence}

In Imamieh Jurisprudence, perjury is among those crimes that holy legislator hasn't considered any given Had for it. False witnesses must be condemned to Tazziri punishment that is unanimous to Sunnis; however, there is some differences in the quality of Tazir.

Most jurisprudents believe in Taziri punishment for forced false witnesses; however, there is some differences in its type and procedure. In the beginning of Islam, Imam Ali (PBUH) performed such that when he arrested a forced witness, if he was in an unknown place, he was sending him among his tribe to introduce him to that tribe by which on one trusted to him and if that witness was among tradesmen, he was sent him to the market to introduce him in the market to strip off the trust of people to him; then he was returned back to be in the jail for a few days and then released. Therefore, among jurisprudents, forced witness has been described as a Taziri Procedure.

Therefore, introduction punishment is one of Taziri crimes whose main duty is introducing the criminal to society and to decry him and when according to the legislator it is necessary to detect and decry a criminal , in addition to Taziri punishments, it is needed to introduce the criminal to the society as well; therefore, introduction punishment has been accepted among Imamieh and Sunnis jurisprudents as a kind of Taziri punishment (Mofid, 1410, P. 795). Owner of Riaz Al-Masael necessitates introducing the forced witness and says "it is necessary to introduce the forced witness in his homeland to avoid accepting his testimony and others also prevent committing forced witness crime; according to Imam and legislator it is also necessary to punish it by Tazir to eliminate the temper of courage and privacy violations". There is no disagreement between Imamieh jurispeudents in the punishment of forced witness (Tabatabaei, 1397, Vol. 1, P. 1418).

In this case, Sheykh Mofid who is one of persons who doesn't necessitate introducing the forced witness, writes:

"It is necessary to punish the forced witness to less than Hadi punishment and legislator must introduce him in the town letting people know him that he is a forced witness; consequently, no one accepts his words and Muslims avoid referring to him. According to Ibn Edris Helly: "Legislator must apply Taziri punishment for forced witnesses as stated above and introduce him among people to avoid committing such crimes in near future (Shafei, 1403, P. 234).

Stating the punishment of forced witness, Saheb javaher says that it is necessary to apply Taziri punishment for forced witness and legislator could apply it by whipping or introducing it among his tribe and neighborhood to prevent others doing so (Najafi, 1984, P. 176). Among Sunni jurisprudents whether Hanafi, Maleki, Shafei and Hanbali, introducing the force witness to the public is also considered as a punishment; Ibne Godameh also claims consensus among Sunni jurisprudents and said that forced witness must be introduced in public in addition to Taziri punishment (Ibn Godameh, 1405, Vol. 12, P. 154).

By reviewing other jurisprudence texts of Sunnis, it could be concluded that although there is no difference between Sunni jurisprudents in the permit for introducing the false witness to the public; however, it is difference in the permit for Tazir and quality and its value such that some jurisprudents such as Ibn Abi Leili, Salem Ibn Abdallah, Abuhaifeh and some Hanafi Jurisprudents such as Sorkhi, Taziri punishment of a forced witness is the same as introducing him to the public and some other jurisprudents like Abuyousof and Mohammad Ibn Hassan Sheibani (apprentice of Abuhanifeh) in addition to introducing to the public, they require Taziri punishment to four whips and jail as well.

According to the votes of Imamieh and Sunni jurisprudents, it could be stated that all are consensus in permit for introducing the forced witness to the public and the only difference between votes of Imamieh jurisprudents is about order of introducing to the public and because according to someone, it is important to introduce false witness to others, they ordered that it is a requirement, while some others only permitted it. The only difference between Sunni jurisprudents is for cited evidences. Analyzing the jurisprudential basics of introducing the 
committers of forced witness to the public in Imamieh texts, there are three narrations from Samaeh Ibn Mehran, Geyath Ibn Ebrahim and Abdalah Ibn Sanan about legality of introducing the forced witness to the public and all of them cited the words of Imam Sadeg (PBUH) (Mortezaee, 2014, P. 132).

One of such narrations has been cited in different ways from Samaeh Ibn Mehran cited from Imam Sadeg who says forced witnesses are whipped in ungiven number upon the discretion of Imam and says that Imam Sadeg said: "they are introduced to the public to prevent repeating it again. Samaeh said: I asked him " do they repent and reform themselves, if their testimony accepted after this time? He said, when they repent, God will face to them and since that time, their testimony will be accepted. It must be noted that quality of executing the introduction to public in any period was different depending on the type of the crime and style of punishments and means for punishment to such extent that the method of introduction punishment was different at the beginning of Islam comparing to this time. The prevailing method for executing it in the past included riding the false witness in reverse on a donkey with no harness and saddle and turning it around the town and this kind of punishment was the same in sodomy and similar. However, in the discussion of introducing the forced witness to the public, based on permit for turning the criminal while ride on a donkey, there is some differences between both religions Imamieh and Sunnis for crying the order against criminal by himself or by the executive. For example, stating the quality of introducing to the public, Sheykh Toosi says that what is similar is cried against him that this person is a false witness; then know him but he won't be ridden on a donkey and won't cry against himself (Zamani, 2011, P. 129).

\subsection{Legal Effects of Perjury}

Considering Article 650 of Tazirat Law and its note, it could be indicated that in following cases, perjury may cancel the order: if the subject of related testimony is civil issues, testifying false or perjury may cancel the order and condemned person must be returned back and if there is no condemned person, false witness must indemnify (Saleh Validi, 2010, P. 170).

In new Code of Procedure approved in 2013, Article 474, considered proving the false testimony for restoring the proceeding. In this case, it must be stated that provision for including the proceeding restoration for condemned persons individually isn't enough for false testimony of the witnesses but this case must be proved in the court by a final order. Consequently, if someone has been condemned criminally and statements of a few people is the basis for its condemnation, and later it is proved that it was a false testimony with final award, this may require restoration of proceeding and also departure of witnesses from their testimony as expressed before, if it hasn't been determined that they had false testimony, the issues isn't included in the Article for restoring the proceeding (Goldoozian, 2005, P. 366).

Perjury by law is a Taziri crime that according to Article 650, its punishment is of grade 6 . For not having a testimony and hiding it according to current penal law, it isn't considered as a crime (Koosha, 2002, P. 60). The task of perjury remained silent in the Articles of Hodood and blood money and it seems that in such cases we must refer to jurisprudence measures. When witnesses testified on a thing that causing executing the blood money or Had on someone who testified against, upon the request of blood guardian, witnesses must give its blood money and in this case in addition to blood money, false witnesses punished by Tazir (Zamani, 2011, P. 118). However, should witnesses testify on a thing that causing executing Had on someone, because of extrusion of a person who condemned due to such testimony, witnesses must be punished by extrusion Had and witness must indemnify for it and if the condemned dies due to Had punishment, in this case, witnesses must be retaliated, for example they must be killed and or pay for blood money if satisfied by blood guardian (Almoosavi Al-Khomeini, 1403, Vol. 2, problem 39, P. 515). Generally, punishment for perjury could be aggregated. If perjury is about Hodood, blood money or retaliation, the rule of aggregating the punishments will be applied (Zeraat, 2004, P. 501).

\section{Conclusion}

Perjury is among crimes damaging to the criminal justice; acting against criminal justice means behaviors damaging on the rights of people for accessing to judicial system or right of society for pursuing and punishing the criminals. Witness is considered as a reason for proving the dispute both in legal claims and in penal claims and due to the importance and value of proof, the perjury has its specific effects; therefore; reaction of legal systems to this topic is different. In our criminal justice, witness is a way of knowledge and inference of the court for diagnosing the crime of accused. Witness isn't indeed applied in criminal matters and ignoring its way isn't against the accused. Consequently, truth is important and witness may not be applied if isn't true. For elements of such crime, it could be stated that its material element according to Article 650 of Islamic Punishment Law includes: testifying perjury before official authorities in the court; however, for its spiritual 
element, general bad intention of the crime based on the knowledge of the witness to the legal order than respect to the action and its legal ban. In the specific bad intention for perjury, willing that means the intention for committing an act or omission that banned by law. Perjury crime that is a crime that is considered as general bad intention and is among absolute crimes ; thus, obtaining the intention for proving the false as a specific intention or specific bad intention in this crime isn't considered. Punishment for this crime as stated in Article 650 includes three months and one day to two years of jail and or one million and five hundred thousand to twelve million Rls of fine that according to Article 19 of this law, such jail is of Taziri punishments of grade 6 and its fine is of grade 7 and the only Hadi crime that one could commit by perjury is extrusion Had and this is of people's right and executing the punishment is subject to the claim of extruded. Because this crime might result in murder or battery, according to the theory of Imam Khomeini and note of Article 650 of Islamic Punishment Law, perjury in addition to Taziri punishment for this crime might be condemned to retaliation and or paying for blood money. In Imamieh Jurisprudence, testimony is individually accounted as a reason for proving the crime. However, in Iranian Criminal Law, witness isn't applied in criminal matters, but knowledge and inference of the judge is applied for diagnosing the crime of the accused. In Imamieh jurisprudence and penal law of Iran, conditions and elements of testimony is different. For justice, according to some jurisprudents, good appearance is enough for proving the justice ; however in new law, Islamic Punishment Law isn't enough for obtaining the justice. For criminal liability of perjury among penal jurisprudence and criminal system of Iran, it could be stated that if due to perjury, a damage whether material or spiritual incurred on a person, the false witness has criminal liability against it and by law it will be punished to jail or paying for fine and in the jurisprudence, construing to forced witness followed by damage and loss to a person testified against, the punishment includes Tazir, Hodood, retaliation and blood money. If by perjury, there is only a material loss of a person, Tazir punishment includes whipping and Hadi whip is lower; but if it makes life loss on a person, the false witness will be retaliated or must pay for blood money and according to Jurisprudence, the false witness must be introduced to the public while crying that he is a liar to punish him and being a lesson for others unless he regrets and reclaims and for punishing a false witness like other crimes it is necessary to have material and spiritual elements and in addition to presence of such elements, the provision for pursuing it includes presence of conditions such as maturity and wisdom and willing and intention and way of proving a perjury crime is like crimes of confession, testimony and knowledge of the judge and documents and provision for fulfilling a perjury is testifying before official authorities in the court followed by damage to a person testified against. Finally, the judge who issued the award and execution officer when they don't know a false testimony have no responsibility for; however, guardian of person testified in favor if colluding to witnesses or knowing the perjury is accomplice and will be punished based on the crime.

\section{References}

Bahrami, B. (2008). requirements of reasons for proving legal and penal claims (1st ed.). Negah Bayeneh, Tehran.

Goldoozian, I. (2005). Reasons for proving the dispute (legal and penal claims), applicable and scientific (2nd ed.). Tehran, Mizan.

Hojati, S. M. (2005). Islamic Punishment Law in current legal system. Tehran, Mithag Edalat.

Katoozian, N. (2009). proof and reasons for proof. Mizan Press, Tehran.

Katouzian, N. (2006). Introduction to Law Science, Enteshar Cooperative, $50^{\text {th }}$ press, Tehran.

Kelarson, C. (2011). Analysis of basics for Public Criminal Law, translated by Mir Mohammad Sadeghi, Hossein, Jangale Javdaneh press, Tehran.

Khaleghi, A. (2011). Code of Proceeding (10th ed.). Tehran, Shahre Danesh.

Koosha, J. (2002). Crimes against Criminal Justice. Tehran, Mizan.

Langroodi, J., \& Jafar, M. (2000). Legal Encyclopedia (Vol. 5, 1st ed.). Tehran University Press.

Langroodi, J., \& Jafar, M. (2002). expanded in law terminology (2nd ed.). Ganje Danesh.

Mofid, M. (1410). Al-Magnaae (2nd ed.). Islamic Publication Press, Qom.

Mortezaei, A., Rokni, M., Asgar, A., Ali, S., \& Malek Afzali, M. (2014). studying the semantics of forced testimony and necessity for introducing to the public in the jurisprudence of Khamse religions. Jurisprudential Researches Quarterly and Islamic law, (35).

Sadri, S. M. (2009). proceeding in translation (3rd ed.). Legal Thoughts Press. 
Saleh Validi, M. (2010). Crimes against Legal Justice and Authority and Public Discipline. Jangal Press, Tehran. Shams, A. (2013). Civil Proceeding, advanced period (Vol. 3, 26th ed.). Tehran, Darak Press.

Shokri, R., \& Sirus, G. (1999). Islamic Punishment Law in current legal system (7th ed.). Tehran, Mohajir. Zeraat, A. (2004). Code of Civil Proceeding in Legal System of Iran. Tehran, Khate Sevom.

\section{Copyrights}

Copyright for this article is retained by the author(s), with first publication rights granted to the journal.

This is an open-access article distributed under the terms and conditions of the Creative Commons Attribution license (http://creativecommons.org/licenses/by/4.0/). 